Четвертий, заключний етап, включав в себе роботу по утриманню стендів, альбомів і т.п. 3 досліджуваної проблеми (небезпеки). Тут ми використовували метод «занурення» в моделююче середовище. Доречним в даному випадку ми порахували використання можливостей образотворчої діяльності (малювання, аплікація, ліплення)

Таким чином, на основі проведеної дослідно - експериментальної роботи з формування компетентності основ безпеки життєдіяльності в учнів початкової школи 3 порушеннями інтелектуального розвитку можна зробити висновок про те, що виявлені нами і реалізовані способи і засоби формування основ безпеки життєдіяльності $\epsilon$ ефективними.

\title{
Література:
}

1. Воронов, А.И Философский анализ понятия виртуальная реальность [Текст] / А.И Воронов - СПБ.: 2004. - 56 с.

2. Запорожець О. Як згортається навчання з питань охорони праці / О. Запорожець, А. Русаловський, О. Цибульник // Охорона праці. 2009. - № 8. C. 14-16.

3. Мамаева, 3.М. Введение в моделирование [Текст] / 3.М. Мамаева. - Н. Новгород: ННГУ, 2005 - 145 с.

4. Сластенин В. А. Педагогика : учеб. пособ. для студ. высш. учеб. завед. / В. А. Сластенин, И. Ф. Исаев, Е. Н. Шиянов. - М. : Академия, 2002. $-576 \mathrm{c}$.

DOI https://doi.org/10.30525/978-9934-26-041-4-55

\section{ТЕОРЕТИЧНІ АСПЕКТИ ПРОСКТУВАННЯ БЕЗПЕЧНОГО ОСВІТНЬОГО СЕРЕДОВИЩА ЗАКЛАДІВ ОСВІТИ}

\author{
Місяк Ю. В. \\ викладач кафедри педагогіки, психології, початкової освіти \\ та освітнього менеджменту \\ Комунальний заклад «Харківська гуманітарно-педагогічна академія» \\ Харківської обласної ради \\ м. Харків, Україна
}

Третє тисячоліття характеризується новою хвилею реформ у системі вищої освіти. Оновлення змісту освіти України грунтується на засадах 
упровадження сучасних освітніх технологій, виховання національної свідомості, нового бачення мети і змісту навчання, виховання та розвитку молодого покоління.

Сучасній Україні потрібні конкурентноспроможні фахівці. Особливої актуальності набуває проблема підготовки вчителів нової генерації, які повинні бути не лише компетентними на фаховому рівні, a й бути високоморальними та відповідальними. Формування гармонійно розвиненої особистості як фахівця - основна мета сучасної системи освіти [1, с. 26].

Нині організація освітнього середовища забезпечується як на рівні держави (закони України «Про освіту» [2], «Про повну загальну середню освіту» [3], «Про вищу освіту» [4] тощо), закладу освіти (посадові інструкції, інструктажі з питань охорони праці та безпеки життєдіяльності тощо), так і на рівні науково-педагогічних та педагогічних працівників із метою формування в них активної ролі у створенні безпечного освітнього середовища.

Із метою модернізації шкільної інфраструктури, створення умов для надання якісних та доступних освітніх послуг в умовах децентралізації та реформи Нової української школи, ініційований Міністерством регіонального розвитку, будівництва та житлово-комунального господарства України проєкт Новий Освітній Простір, реалізується спільно з Міністерство освіти і науки України та органами місцевого самоврядування. Новий освітній простір забезпечує сукупність умов, засобів та технологій, що утворюють безпечне та доступне освітне середовище із застосуванням сучасних інформаційно-комунікаційних засобів та технологій у процесі здобуття освіти, у тому числі новітніх технологій енергоефективності, новітніх технологій дизайну, архітектури будівель, споруд та територій закладів освіти [5].

Дослідженням проблеми формування безпечного освітнього середовища займались зарубіжні (І. Баєва, Є. Величко, Л. Гаязова, Г. Коджаспірова, В. Пилипенко, М. Чесноков та інші) і вітчизняні (В. Білоус, І. Обозова, Н. Цікановська, Л. Шевченко та інші) дослідники в галузі педагогіки і психології.

Осмислення умов, за яких освітнє середовище буде безпечним, розглядали В. Воронцов, Ю. Мануйлов, В. Слободчиков, Ю. Песоцький, В. Ясвін та ін.

Над проблемою соціально-психологічної безпеки освітнього середовища працюють В. Баєва, Е. Лактіонова, А. Журавльов, Н. Іванова, М. Кашапов, О. Марченко, В. Рубцов та ін.

Проблеми організації освітнього середовища висвітлені у працях багатьох дослідників (В. Ясвін, І. Баєва, А. Каташов та ін.). 
У психолого-педагогічній літературі безпечне освітнє середовище школи часто розглядається й описується як «ефективне», «комфортне», «гуманне», «оптимальне», «сприятливе» для діяльності, стосунків і гармонійного особистісного розвитку його суб'єктів. На думку І. Баєвої психологічно безпечне освітнє середовище закладу - це середовище, вільне від проявів психологічного насильства у взаємодії, яке сприяє задоволенню потреб у особистісно-довірчому спілкуванні, створює референтну значимість середовища та забезпечує психічне здоров'я учасників освітнього процесу [6].

Л. Сидорова під безпечним освітнім середовищем розуміє середовище прогнозування, виявлення та усунення на різноманітних рівнях небезпек та ризиків досягнення якості освіти [7].

Варто зазначити, що проблема побудови структури безпечного освітнього середовища мало досліджена.

Одним із небагатьох авторів, які досліджують питання саме безпечного освітнього середовища є О. Обозова, яка виділяє такі його компоненти:

- матеріально-технічні умови праці та навчання (архітектурноестетична організація життєвого простору суб'єктів освітнього процесу);

- змістовно-методичні умови (концепція функціонування закладу освіти; система виховної роботи; освітні програми; технології, форми, методи організації діяльності освітньої установи);

- стосунки «педагог - педагог», «педагог - учень», «учень - учень»;

- безпечна особистість (знає про існування різних джерел небезпек; розуміє, що $є$ передумови для виникнення і подолання небезпек; виступає як активний суб'єкт, здатний запобігти небезпечним ситуаціям або вийти з них без шкоди для себе та інших людей) [8, с. 5].

Ми погоджуємось із думкою Г. Костецької, яка вбачає важливою умовою формування безпечного освітнього середовища усвідомлення адміністрацією та працівниками закладу освіти сутності та структури такого середовища, врахування педагогами в процесі професійної діяльності взаємозв'язку між його компонентами. Дослідниця наголошує, що саме педагогічний колектив виступає ключовим ресурсом становлення і розвитку в закладі освіти безпечного освітнього середовища $[9$, с. 49-51].

Ураховуючи сучасні соціально-політичні й економічні зміни в українському суспільстві стає зрозумілим наскільки важливими $€$ питання формування безпечного освітнього середовища в закладах освіти, збереження та примноження психічного й психологічного здоров'я здобувачів освіти і учителів. Освітнє середовище повинно 216 
бути безпечним для усіх його суб'єктів, оскільки без цього неможливе функціонування закладу освіти загалом.

\section{Література:}

1. Гаркович О. Л. Педагогічне проектування освітнього середовища професійної підготовки майбутнього вчителя хімії. Науковий вісник Ужгородського національного університету. Серія «Педагогіка. Соиіальна робота». 2015. Вип. 37. С. 26-28.

2. Про освіту: Закон України від 05.09.2017 p. № 2145-VIII (iз змінами № 978-IX від 05.11 .2020 p). URL: https://zakon.rada.gov.ua/laws/show/2145-19\#Text (дата звернення: 15.01.2021).

3. Про повну загальну середню освіту: Закон України від 16.01.2020 р. № 463-IX (із змінами № 764-IX від 13.07.2020 p). URL: https://zakon.rada.gov.ua/laws/show/463-20\#Text (дата звернення: 16.01.2021).

4. Про вищу освіту: Закон України від 01.07.2014 p. № 1556-VII (із змінами № 849-IX від 02.09 .2020 p). URL: https://zakon.rada.gov.ua/laws/show/1556-18\#Text (дата звернення: 16.01.2021).

5. Новий освітній простір. Інформаційний посібник. 1 липня 2019 p. URL: https://www.minregion.gov.ua/wp-content/uploads/ 2019/06/NOP_Energoefektivnist.pdf

6. Рубцов В. В., Баева И. А. Психологическая безопасность образовательной среды как условие психосоциального благополучия школьника. Безопасность образовательной среды: сб. статей. 2008. Ч. 1. С. 5-11.

7. Сидорова Л. 3. Проектирование педагогических ситуаций как средство организации безопасной образовательной среды педагогического колледжа: автореф. дис. ... канд. пед. наук: 13.00.01 / Іркуцьк, 2008.

8. Обозова О. Психологічна безпека освітнього середовища. Психолог. 2011. № 10 (442). С. 3-6.

9. Костецкая Г. А. Средовый подход в образовании: безопасная образовательная среда современной школы. Молодой ученый. 2014. № 18.1. C. $49-51$. 